\title{
Bir Konaklama İşletmesinin Alakart Restoranında Kaynak Tüketim Muhasebesi Uygulaması ${ }^{1}$ (Araştırma Makalesi)
}

\section{Resource Consumption Accounting Application in A la carte Restaurant of A Accommodation Enterprise}

Doi: 10.29023/alanyaakademik.673394

\section{Ayşe KURTLU}

Dr. Öğr. Üyesi, Karabük ̈̈niversitesi, Safranbolu Turizm Fakültesi

ayseergul@karabuk.edu.tr

Orcid No: 0000-0001-8543-5617

\author{
Şengül SELÇUK \\ Uzman, KarabükÜniversitesi, Lisansüstü Eğitim Enstitüsü \\ sengulselcuk@windowslive.com \\ Orcid No: 0000-0003-0178-0152
}

Bu makaleye atıfta bulunmak için: Kurtlu, A. \& Selçuk, Ş. (2020). Bir Konaklama İşletmesinin Alakart Restoranında Kaynak Tüketim Muhasebesi Uygulaması. Alanya Akademik Bakış, 4(2), Sayfa No.261281.

\begin{abstract}
Anahtar kelimeler:
Maliyet Muhasebesi, Çăgdaş Maliyet

Yöntemleri,

Kaynak Tüketim

Muhasebesi,

Konaklama İsletmesi

Makale Geliş Tarihi:

10.01.2020

Kabul Tarihi:

07.05.2020

\section{ÖZET}

Küreselleşmeyle birlikte rekabetin küresel bir boyut kazanmasl, teknolojik gelişmeler, üretim tekniklerinin gelişmesi ve otomasyonun artması, ürün yaşam dönemlerinin klsalması ve ürün çeşitliliğinin artması tüm alanlarda olduğu gibi muhasebe alanını da etkilemiş ve yeni maliyetleme yöntemleri arayışına girilmiştir. Bu koşullar dikkate alındığında, diğer tüm işletmeler gibi konaklama işletmeleri de yoğun rekabet ortamında maliyetlerini etkili bir şekilde kontrol etmek için çağdaş maliyet yöntemlerini uygulamak durumundadır. Bu yöntemlerden biri de kaynak tüketim muhasebesidir. Çalışmanın amacl, turizm işletmelerinde kaynak tüketim muhasebesi yöntemiyle atıl kapasitenin belirlenmesini, analiz edilerek azaltılmasinı ve maliyetlerin kontrol altına alınarak minimize edilmesini sağlamaktır. Bu amaçla Antalya'da beş yıldızlı bir konaklama işletmesinin alakart restoranında kaynak tüketim muhasebesi (KTM) uygulaması gerçekleştirilmiştir. Elde edilen bulgulara göre konaklama işletmesinin alakart restoranında 2019 Ağustos ayında 2.816,20 TL atıl kapasite maliyeti bulunmaktadır. Atıl kapasite maliyeti ürünlere dağıtılmayarak dönem gideri olarak alınmıştır.
\end{abstract}

\begin{abstract}
The globalization of competition with globalization, technological developments, the development of production techniques and automation,
\end{abstract}

\footnotetext{
${ }^{1}$ Çalışma, Şengül Selçuk, "Turizm İşletmelerinde Geleneksel Maliyet Yöntemlerine Alternatif Bir Uygulama Önerisi: Kaynak Tüketim Muhasebesi”, Karabük Üniversitesi, Lisansüstü Eğitim Enstitüsü, Yüksek Lisans tezinden üretilmiştir.
} 
Keywords:

\author{
Cost Accounting, \\ Contemporary \\ Costing Methods, \\ Resource \\ Consumption \\ Accounting, \\ Accommodation \\ Enterprise
}

the shortening of product life periods and the increase in product variety have affected the accounting field as well and new costing methods have been searched. Under these circumstances, accommodation enterprises, like all other enterprises, have to apply contemporary cost methods to effectively control their costs in an intense competitive environment. One of these methods is resource consumption accounting. The aim of this study is to determine the idle capacity in tourism enterprises by using resource consumption accounting method, to analyze and reduce it and to minimize the costs by controlling. For this purpose, resource consumption accounting (RCA) was implemented in the a la carte restaurant of a five-star accommodation enterprise in Antalya. According to the findings, there is an idle capacity cost of TL 2,816.20 in August 2019 in the a la carte restaurant of the accommodation enterprise. The idle capacity cost is not allocated to the products and is taken as expense.

\section{GİRIŞ}

Üretim ortamlarına teknolojinin getirdiği değişim ve gelişmeler sonucu 80'li yıllardan itibaren kullanılagelen geleneksel maliyet yöntemleri ile ilgili yetersizlikler daha çok kendini göstermiştir. İşletmeler rekabet edebilirliklerinde yetersiz olduklarını anlamasıyla birlikte bu yetersizlikleri çözme yoluna gitmiştir. Geleneksel maliyet yöntemlerindeki yetersizliklerin literatüre geçmesi de yine 80'li yıllarda olmuştur (French, 1980: 18-19). Bu dönemde araştırmacılar ve akademisyenler geleneksel yöntemlerin eksikliklerini araştırıp geliştirilmesi ya da değiştirilmesi gereken yönleri ortaya koymuştur. Geleneksel yöntemlerdeki eksikliklerin fark edilmesiyle ve teknolojik gelişmelerin de etkisiyle üretim tekniklerinde ve muhasebe sistemlerinde hızlı bir değişim yaşanmıştır. Emek yoğun sistem yerini sermaye yoğun bir anlayışa bırakmıştır. Üretim maliyetlerindeki direkt işçiliklerin payı azalmış genel üretim giderlerinin payı artmıştır. Bununla birlikte işletmelerdeki sabit giderler artarken değişken giderler azalmıştır (Charlos ve Bader, 1986: 106-107). Maliyetlerin yapısındaki değişime rağmen direkt işçilik saatinin dağıtım anahtarı olarak kullanılması faaliyetler ile maliyetler arasındaki ilişkiyi net olarak yansıtmamakta ve işletme kararlarının alınmasında hatalı sonuçlara neden olmaktadır. Özellikle genel üretim giderlerinin sadece üretim hacmiyle ilişkilendirilmesi yöneticilerin yanlış bilgilenmesine ve yanlış kararlar almasına yol açmaktadır (Lewis, 1993: 99). Üretim hacmi genel üretim giderlerinin oluşmasında belirleyici bir faktör olmamakta ve genel üretim giderlerinin hacim temelli dağıtım anahtarıyla dağıtılması maliyet bilgilerinin doğruluğunu engellemektedir (Öker, 2003: 18; Kaygusuzoğlu, 2010: 249; Gümüş, 2012: 111).

Üretim ortamlarındaki değişim ve gelişmelerin yanı sıra ürün yaşam dönemlerinin kısalması, müşteri istek ve ihtiyaçlarındaki hızlı değişim iş dünyasını ve piyasa koşullarını daha da karmaşıklaştırmıştır (Aksoylu ve Dursun, 2001: 358). Yoğun ve küresel rekabet nedeniyle işletmeler ürün farklılaştırma yoluna gitmiştir. Bu durum sonucunda ürün çeşitliliğinin fazla olduğu ancak az miktarda üretildiği yeni üretim metotları geliştirilmiştir (Kaygusuzoğlu, 2010: 245). Küresel ve yoğun rekabet ayrıca işletmeleri daha ileri teknolojiler kullanma ve yeni üretim sistemleri geliştirmeye yöneltmiştir (Altınbay, 2006: 141-142). Sürekli değişmekte olan piyasa koşulları ve gelişen teknoloji, maliyet yönetimi kavramlarında da yeni anlayış ve gelişmeleri gerektirmektedir. Çünkü geleneksel maliyet yöntemleri, bu gelişim ve değişimler nedeniyle işletmelerin ihtiyaçlarına cevap vermede yetersiz kalmaktadır. $\mathrm{Bu}$ 
nedenle maliyet yöntemleri de çağın gereksinimlerine cevap verecek nitelikte olmak zorundadır (Hacırüstemoğlu ve Şakrak, 2002: 7).

Yukarıda açıklanan ve araştırmanın temel problemini oluşturan değişim ve gelişimler turizm sektörünün bel kemiği olan konaklama işletmelerini de etkilemektedir. Konaklama işletmeleri her ne kadar emek yoğun özellikte olsa da gelişen teknoloji ile birlikte otomasyon belli bir oranda artmıştır. Otomasyonun artması sonucunda yiyecek içecek bölümü gibi bölümlerde üretim teknolojileri gelişmiş, makineleşme nedeniyle endirekt giderler artmış buna karşın direkt işçilikler belli bir oranda azalmıştır. Birden fazla ürün ya da hizmetin üretildiği konaklama işletmelerinde doğru maliyet bilgilerine ulaşmak oldukça önem kazanmıştır.

Konaklama işletmeleri bütünleşik hizmet sunan, konaklamanın yanında yeme içme, eğlence, toplantı gibi birçok faaliyeti yerine getiren hizmet işletmeleri niteliği taşımaktadır. $\mathrm{Bu}$ bakımdan konaklama işletmelerinde maliyetlerin etkin bir şekilde kontrol edilmesi, karlılığın artırılarak yoğun rekabet ortamında varlığını koruyabilmesi ancak etkin bir maliyet yöntemi ile mümkün olabilmektedir.

Bir işletmede ne kadar çok faaliyet varsa o kadar çok kaynak ihtiyacı olacaktır. Çoklu kaynak kullanılması da işletmelerin kaynak maliyetlerini doğru bir şekilde saptayabilecek maliyet yöntemine olan ihtiyacını arttıracaktır (Unutkan, 2010: 93). Ayrıca geleneksel yöntemler, ürün yaşam dönemi maliyetlerini göz ardı ederek sadece üretim maliyetlerine odaklanmakta ve konaklama işletmelerinde (Kurtlu vd., 2017: 522) ürün ve hizmetlerin tasarım aşamasından müşteriye ulaşmasına kadar olan süreçte kullanılan kaynaklara ait maliyetler konusunda doğru bilgiler sağlamakta yetersiz kalmaktadır (Karğın, 2013: 24). Bu yetersizlikler neticesinde özellikle 80 'li yıllardan itibaren çağdaş maliyet yöntemleri gelişme göstermeye başlamıştır.

Çağdaş maliyet yöntemleri daha çok modern üretim ortamları olarak da nitelendirilen teknolojinin yoğun olarak kullanıldığı, ürün çeşitliliğinin, kaynakların ve faaliyetlerin fazla olduğu işletmelerde faydalı olan yöntemlerdir. Konaklama işletmeleri de her ne kadar sektörel özellikleri gereği emek yoğun işletmeler olsa da kaynak, faaliyet ve ürün çeşitliliğinin fazla olması nedeniyle çağdaş maliyetleme yöntemlerini uygulamaları halinde maliyet etkinliği ve kontrolü sağlama imkanı bulmaktadırlar. Böylece doğru maliyet bilgileri ile stratejik kararlarında daha etkin ve verimli sonuçlara ulaşmaktadırlar. Ayrıca giderlerini ölçme ve kontrol etmede, işletme başarısını değerlendirmede daha başarılı olmakta, rekabet koşullarına ayak uydurarak müşteri tatmininde daha verimli olabilmektedirler. $\mathrm{Bu}$ yöntemlerinden biri de kaynakların kullanımına ve kaynakların analizine odaklanarak, atıl kapasite kontrolü, maliyet yönetimi ve dolayısıyla işletmelere rekabet avantajı sağlayan kaynak tüketim muhasebesidir.

Çalışmanın amacı, konaklama işletmelerinde KTM yöntemiyle işletmenin atıl kapasitesini belirleyerek analiz etmek ve böylece işletmede maliyet etkinliği sağlamaktır. Bu amaçla Antalya'da faaliyet gösteren beş yıldızlı bir konaklama işletmesinin alakart restoranında KTM uygulaması gerçekleştirilmiştir.

\section{KAYNAK TÜKETIM MUHASEBESI}

KTM'nin ortaya çıkmasıyla ilgili ilk gelişme Alman yönetim muhasebesi olarak adlandırılan Grenzplankostenrehnung (GPK) ile olmuştur. KTM maliyetlerin özelliklerini, yapılarını ve davranışlarını izlerken faaliyetlere odaklanan ve onları neden sonuç ilişkilerine göre analiz 
eden faaliyet tabanlı maliyetleme (FTM) ve GPK yöntemlerinin birleşmesinden oluşan bir yöntemdir. FTM ve GPK yöntemlerini geliştirerek destekleyen KTM (Wang vd., 2009: 84), daha kapsamlı ve daha doğru sonuçlar üreten bütünleşik bir maliyet yönetim sistemidir (Merwe ve Keys, 2002: 31).

GPK yönteminin kaynaklara odaklanma, FTM yönteminin ise faaliyetlere odaklanma özelliğini alan KTM, GPK ve FTM'ye kıyasla daha entegre bir maliyetleme yöntemidir (Weber ve Clinton, 2004: 1). FTM'de kaynak maliyetleri, önce faaliyetlere, daha sonra ürünlere dağıtılmak üzere iki aşamada gerçekleşmektedir. KTM'de ise kaynak maliyetleri önce kaynak havuzlarında toplanıp faaliyetlere, faaliyet havuzlarında toplanan maliyetler ise ürünlere dağıtılmaktadır (Aktaş, 2013: 60). FTM'den ve geleneksel maliyet yöntemlerinden farklı olarak KTM, atıl kapasite maliyetlerini ürünlere yüklemeyerek dönem gideri olarak almaktadır (Karaca ve Küçük, 2017: 357). Wegmann (2009: 13-14) FTM faaliyetlere gereğinden fazla odaklanarak faydasız ve alakasız analizlere neden olduğu için uygulama alanı bulamamıştır. KTM ise aksine işletme yöneticilerine işlemlerle ilgili açık ve net bilgiler sunmaktadır (Aktaş, 2013: 59).

Maliyetlere nelerin sebep olduğu sorusuna KTM'nin cevabı kaynaklardır (White, 2009: 6465). KTM'ye göre kaynaklar yalnızca faaliyetlerin kullandığı kaynaklardan değil aynı zamanda kaynakların kendi içinde kullandığı kaynakları da kapsamaktadır. Yöntem, maliyet hesaplaması yaparken kaynak tüketimini temel almakta, diğer bir ifadeyle maliyetleri kaynak kullanımına göre dağıtmakta ve maliyetlerin işletme içi bir bölümden diğer bölüme geçişini sağlamaktadır (Wang vd., 2009: 84).

KTM'nin kaynak odaklı ve miktar temelli anlayışa sahip olması detaylı bir maliyet analizini kullanılmasını gerektirmektedir. Yöntem işletme yöneticilerine karar alma sürecinde ürün temelli değil kaynak temelli bilgiler sunmaktadır (Köse ve Ağdeniz, 2015: 59). Yöntem işletmeleri kaynak bazında ele alarak, işletmelere tüketilen kaynakları ve bu kaynakların maliyetlerini detaylı analiz imkânı vermektedir (Karaca ve Küçük, 2017: 356). Ayrıca, maliyet hesaplaması yaparken kaynak tüketimini dikkate alarak ürünlere tükettiği kaynaklara göre maliyet dağıtımı yapmaktadır (Wang vd., 2009: 84).

KTM'nin en belirgin özelliği atıl kapasitenin izlenmesi, tarihi maliyetlerden çok yerine koyma maliyetlerinin kullanılması ve farklı seviyelerdeki maliyet bilgilerini takip etme ve sınıflandırma imkanı vermesidir (Peacock ve Juras, 2006: 55). Yöntemde, atıl kapasite belirlenirken kaynak havuzlarında toplanan maliyetler sabit ve değişken olarak sınıflandırılmakta; sabit maliyetler teorik kapasiteye göre, değişken maliyetler ise bütçelenmiş kaynak çıktılarına göre dağıtılmaktadır (Perkins ve Stovall, 2011: 47). Bu ise işletmeye atıl kapasite kontrolü imkanı vermektedir (Karaca ve Küçük, 2017: 356). Kaynak maliyetleri diğer bir ifadeyle ürünlerin tükettikleri kaynakların maliyeti ürünlere dağıtılmakta, atıl kapasite maliyetleri ise ürünlere dağıtılmayıp dönem gideri olarak alınmaktadır (Tse ve Gong, 2009: 42-43). Kaynak havuzlarında toplandıktan sonra sabit ve değişken olarak sınıflandırılan kaynaklar atıl kapasite oranının belirlenmesi için kullanılmaktadır. Sabit maliyetlerin kullanım oranı belirlenirken kaynağın teorik kapasitesi göz önünde bulundurulmakta, değişken maliyetlerin kullanım oranı belirlenirken bütçelendirilmiş kaynaklar dikkate alınmaktadır (Perkins ve Stovall, 2011: 47). Yöntem ayrıca kaynak kapasitelerini, üretken olan, üretken olmayan ve boş kapasite şeklinde sınıflandırmakta ve işletmelere kaynak kullanımları konusunda faydalı bilgiler sunmaktadır (Ahmed ve Moosa, 
2011: 756). KTM uygulamasını benimseyen işletmeler, doğruluk oranı yüksek maliyet bilgilerine, ayrıntılı maliyet analizine sahip olmaktadır (Fisher ve Krumwiede, 2012: 46).

Yöntemde, kapasitenin en gerekli ve makul seviyede kullanılması atıl kapasitenin ya da aşırı kaynak oluşması gibi istenmeyen durumların oluşmasına engel olmaktadır. Yöntem, kapasite kontrolü yaparak işletmenin verimliliğinin artmasını sağlamakta ve işletmeye maliyet kontrolü konusunda büyük ölçüde fayda sağlamaktadır. KTM'ye göre maliyete sebep olan unsurun yani kaynağın ortadan kaldırılması veya süreçteki başka bir faaliyete aktarılması söz konusu olmadıkça maliyet azaltılması söz konusu olmamaktadır (White, 2009: 65).

KTM yönteminin nedensellik, cevaplanabilirlik ve iş/süreç ilişkisi olmak üzere 3 ilkesi aşağıda kısaca açıklanmıştır (White, 2009: 67):

Nedensellik İlkesi, kaynaklar ve kaynakların kullandığı ürünler arasındaki ilişkiyi belirlemede önemli rol oynar (Weber ve Clinton, 2004: 3-4). Bu ilke, kaynak ve kaynak akışlarının ilgili oldukları maliyetlerin neden sonuç ilişkisini yansıtacak şekilde olmasını gerektirir (Aktaş, 2013: 63). Buna göre bir maliyet ile kaynak akışı arasında nedensellik ilişkisi kurulmazsa, bu kaynak akışı ve maliyetlerin yönetilmesinde sorun yaşanması kaçınılmaz olur (Elmacı 2013).

Cevaplanabilirlik İlkesi, nedensellik ilkesine uyum sağlamak amacıyla uygulanır. Bu ilke, kaynak havuzları arasında sabit ve değişken ilişkileri düzenler, kaynak havuzlarının özelliklerini daha ayrıntılı tanımlayarak etkin bir karar destek gelişimine imkan verir (White, 2009: 67; Ahmed ve Moosa, 2011: 756).

İş/Süreç İlkesi, cevaplanabilirlik ve nedensellik ilkeleri gibi yaygın olmasa da gerekli bir ilkedir. KTM'nin diğer ilkeleri kadar ayrıntılı olmayan bu ilke idari kararlar verilmesinde diğer iki ilkeyi destekleyici anlayıştadır (Öğünç ve Tekşen, 2018: 397) ve yöntemde daha sınırlı ve çok disiplinli şekilde uygulanmaktadır (White, 2009: 70).

KTM'nin kaynakların analizi, maliyetlerin nitelikleri ve miktara dayalı olmak üzere 3 temel unsuru bulunmaktadır (Merwe ve Keys, 2002: 31; Wang vd. 2009: 84; White, 2009: 64; Köse ve Ağdeniz, 2015: 53):

Kaynakların Analizi, nedensellik ilkesine göre kaynakların ve kaynakları tüketen maliyet öğeleri arasındaki ilişkinin sorgulanması ve bilinmesi son derece önemlidir (Karaca ve Küçük, 2017: 357). Söz konusu bu ilişkinin, kaynak akışları ile kaynakların ait olduğu maliyetlerin neden sonuç ilişkisini açıklayacak nitelikte olması gerekmektedir (Kurtlu, 2016: 4). Kaynaklar ve kaynak akışları arasındaki sebep sonuç ilişkisini bilmek kaynak maliyetlerini saptamak ve maliyet kontrolü sağlamak açısından büyük önem taşımaktadır. Kaynakların kendi içinde 3 temel özelliği bulunmaktadır. Bunlar (White, 2009: 65-66):

- Yeterlilik; personel oryantasyonu, eğitimi, üretimde kullanılan araçların kalitesi, bakımı gibi nitel özelliklerdir.

- Kapasite; mevcut ya da gelecekteki talebi karşılayacak ölçüde kaynak bulundurulması anlamına gelir ve 3 şekilse sınıflandırılır:

○ Üretken Kapasite; kaynağın amacına odaklanıp, asıl amacına uygun olarak üretim yapmasını ifade eder.

- Üretken Olmayan Kapasite; kaynakların mecburi olmayan amaçlar için kullanılmaması gerektiğini ifade eder. 
- Atıl Kapasite; kaynağın asıl amacını yerine getirmede aksaklığından ya da fazla kapasitede düzenlenmesinden çalışamamasını ifade eder.

- Maliyet Yapısı; maliyetler kaynak ve kaynak havuzlarının çıktılarının akışına bağlıdır ve kaynak maliyetleri kaynak özelliklerini göstermektedir.

Maliyetlerin Nitelikleri: Yöntemde maliyetler nitelik açısından birincil ve ikincil maliyetler olarak sınıflandırıldıktan sonra sabit ve değişken olup olmadığı kaynak havuzlarından çıkan çıktı ve maliyet ilişkisine göre belirlenmektedir. Birincil maliyetler kaynak havuzunda üretilen maliyetler iken ikincil maliyetler ise söz konusu kaynak havuzuna diğer kaynak havuzlarından aktarılan maliyetlerdir (White, 2009: 74). Bir kaynak havuzunda oluşan birincil maliyetler üzerinde bu kaynak havuzu birincil kontrole sahipken, söz konusu kaynak havuzuna diğer kaynak havuzlarından gelen ikincil maliyetler üzerinde ikinci derecede kontrole sahiptir (Merwe ve Keys, 2002: 4). Her iki maliyet türü de kaynak havuzunu desteklemektedir ancak birincil maliyetler kaynak havuzlarında üretilirken ikincil maliyetler başka kaynak havuzlarından aktarılmış maliyetlerdir (White, 2009: 75). Örnek vermek gerekirse çalışmada işçilik kaynak havuzunda üretilen maliyetler birincil maliyetlerdir ve işçilik kaynak havuzu bu maliyetler üzerinde birincil kontrole sahiptir. İşçilik kaynak havuzuna diğer kaynak havuzlarından maliyet aktarılmamıştır. Dolayısıyla ikincil maliyetler işçilik kaynak havuzu için söz konusu değildir. Çalışmada işçilik kaynak havuzunun birincil ve ikincil maliyetleri belirlendikten sonra bu maliyetlerin sabit ya da değişken olup olmadığı belirlenmiştir.

Miktara Dayalı Yöntem, tüketim ilişkilerinin belirlenmesinde ölçüt olarak miktarı baz almaktadır. Yöntemin temel hedefi kaynakların ürünler ve faaliyetlerdeki, faaliyetlerin ürünlerdeki tüketim oranlarının saptanması ve maliyetlemede faaliyet ve kaynak tüketim oranlarının ölçü olarak alınmasıdır. Böylece KTM ve maliyetlerin dağıtımı arasında nedensellik ilkesi miktara göre belirlenmiş olmaktadır (Wang vd. 2009, s. 84). Buna göre faaliyetler, miktar temelli belirlenmiş faktörleri içermeli ve girdileri miktar temelli kullanmış olmalıdır (White, 2009: 70). KTM'de tüm faaliyetler miktara dayalı diğer bir ifadeyle kaynak ve faaliyet kullanım oranları saptanırken ölçümlerle ölçülebilen standartlara göre yapılmaktadır (Köse ve Ağdeniz, 2015: 57).

KTM yönteminin uygulama süreci aşağıda kısaca açıklanan aşamalardan oluşmaktadır (Perkins ve Stovall, 2011: 47):

Kaynakların Birbiriyle Ilişkisinin Incelenmesi ve Kaynak Havuzlarının Belirlenmesi: Yöntemde kaynaklar temel alınmakta, kaynaklar ve birbirleriyle ilişkileri incelenerek kaynak havuzları oluşturulmaktadır. Birbiriyle ilişkisi olan kaynaklar aynı kaynak havuzunda toplanmaktadir.

Birincil ve İkincil Maliyetlerin Belirlenmesi: Her kaynak havuzunun birincil maliyetleri ve varsa ikincil maliyetleri belirlenmekte ve toplam maliyetleri hesaplanmaktadır. Yöntem, kaynakları kaynak havuzunda topladıktan sonra birincil maliyetler ile diğer maliyet havuzlarından aktarılan ikincil maliyetleri ayırmaktadır (Balakrishnan vd., 2012: 13).

Kaynak Havuzlarında Toplanan Maliyetlerin Sabit ve Değişken Olarak Ayrılması: Önceki aşamada birincil ve ikincil olarak belirlenen maliyetler bu aşamada sabit ve değişken olarak ayrılmaktadır. Maliyetlerin sabit ve değişken olarak ayrılma nedeni sabit maliyetlerin teorik 
kapasiteye; değişken maliyetlerin ise kaynak havuzunun çıktı miktarına (pratik kapasiteye) göre dağıtılmasıdır.

Faaliyet Maliyetlerinin Belirlenmesi: Sabit ve değişken olarak ayrılan maliyetler kaynak etkenleri (dağıtım anahtarları) vasıtasıyla faaliyetlere dağıtılmakta ve böylece faaliyetlerin maliyetleri belirlenmektedir. Her kaynak havuzunun kapasitesi teorik kapasiteyle karşılaştırıldığında atıl kapasite ve atıl kapasite maliyetine ulaşılmaktadır.

Faaliyetleri Kullanan Ürünlere Maliyetlerin Dağıtılması: Bir önceki aşamada belirlenen faaliyet maliyetleri, ürünlere faaliyetleri kullanma miktarı ile orantılı bir şekilde dağıtılmakta ve böylece ürün maliyetleri ortaya çıkmaktadır.

\section{BEŞ YILDIZLI BİR KONAKLAMA İŞLETMESINIIN ALAKART RESTORANINDA KTM UYGULAMASI ${ }^{2}$}

\subsection{Araştırma Yapılan İşletmenin Tanıtılması ${ }^{3}$}

Uygulama yapılan konaklama işletmesi 2007 yılından beri Antalya'da faaliyet gösteren beş yıldızlı bir işletmedir. İşletmede 7 farklı tipte ve büyüklükte 567 oda bulunmaktadır. İşletmede 1 ana restoran (açık büfe hizmeti sunulan), 1 İtalyan restoran, 1 Uzakdoğu restoranı ve 1 alakart restoran, 3 snack restoran, 8 bar, 1 pastane, gözleme evi ve pide firını ile yiyecek içecek hizmeti verilmektedir.

Araştırmanın uygulaması konaklama işletmesinin alakart restoranında yapılmıştır. Konaklama işletmesinin alakart restoranında 25 adet 4 kişilik masa bulunmakta ve aynı anda 100 kişi ağırlanabilmektedir. Alakart restoran rezervasyon ile çalışmakta olup 100 kişi tamamlanınca o gün için rezervasyon alınmamaktadır. Restoran saat 19:00-23.30 saatleri arası hizmet vermektedir. Alakart restoranda mönü aylık olarak düzenlenmektedir. Alakart restoranın mönüsü Tablo 1'de de görüleceği üzere çorbalar (sebzeli enginar çorbası, sütlü fesleğenli domates çorbası, sebzeli tavuk çorbası), mezeler (havuçlu kerevizli meze, tarator, piyaz), salatalar (Akdeniz salatas1, avokadolu domates salatas1, roka salatas1), ana yemekler (kremalı mantar soslu biftek, beşamel soslu patatesli tavuk, firında çupra/levrek) ve tatlılar (tahinli kabak tatlısı, sütlaç, meyve) olmak üzere 5 guruptan oluşmaktadır. Fiyatlandırma ise müşterinin yediği yiyecekleri ayrı ayrı değil mönüdeki her bir yemek gurubundan istediği yiyeceği seçtiği ve buna göre tek bir fiyat üzerinden yapılmaktadır. Konaklama işletmesinin alakart restoranı ağustos ayında her gün dolu olup günde 100 aylık 3.100 adet akşam yemeği (fiyat sabit olduğu için 5 yemek grubundan ayrı ayrı aylık 3.100 adet olmak üzere toplam 15.500 porsiyon) üretilmiştir.

Konaklama işletmesinin alakart restoranından alınan ve uygulamada kullanılan veriler 2019 Ağustos ayına aittir. Ağustos ayı mönüsünün bir porsiyonda net olarak ne kadar kullanıldığ1 belli olmayan dolayısıyla maliyeti ürüne doğrudan yüklenemeyen madde ve malzemeleri ifade eden endirekt madde ve malzemeleri kişniş, nar ekşisi, tuz, sıvı ve katı yağlar, sarımsak, un, domates salçası, karabiber, pul biber, kekik, kimyon, defne yaprağı, toz fesleğen, krema, sirke, ceviz içi, tahin, pirinç unu, nişasta, pirinç, şeker, maydanoz, marul ve lolorosso'dur. Ağustos 2019 alakart restoranda kullanılan söz konusu 26 çeşit endirekt madde ve malzeme

\footnotetext{
${ }^{2}$ Araştırmanın uygulamasında Okutmuş (2015) ve Kurtlu (2016) çalışmalarından faydalanılmıştır.

${ }^{3}$ Çalışma, Antalya'da faaliyet gösteren beş yıldızlı bir konaklama işletmesinin alakart restoranında yapılmıştır. İşletmenin ismi rekabet ve ticari verilerin güvenliği açısından gizli tutulmuştur.
} 
yemeklerin ana maddesi olmayıp bir porsiyonda tutam, avuç, dal, diş, çay/tatlı/yemek kaşı̆̆ 1 gibi miktarı durumdan duruma değişen ve net olarak hesaplanamayan ölçeklerle yemeklere eklenmektedir. Miktar bilgileri işletmenin standart reçetelerinden yaklaşık olarak alınmış ve söz konusu yiyeceğin aylık üretimi ile çarpıldıktan sonra aylık kullanım miktarına ulaşılmıştır. Maliyet bilgileri ise satınalma bölümünden alınan kilogram fiyatları baz alınarak hesaplanmıştır.

Uygulama yapılan alakart restoranda 6 aşçı, 3 yamak, 6 garson, 3 komi, 1 bulaşıkçı, 1 restoran şefi ve 1 mutfak şefi olmak üzere 21 personel çalışmaktadır. 1 aşçı ve 2 yamak hazırlık faaliyetinde; 5 aşçı, 1 yamak, 1 bulaşıkçı ve 1 mutfak şefi pişirme faaliyetinde; 6 garson, 3 komi ve 1 restoran şefi sunum faaliyetinde görev almaktadır. Çalışanlar haftada bir gün izin kullandığı için ayda toplam 26 gün çalışmaktadır. Restoranda yiyeceklerin üretilmesinde 6 ocak, 1 firın, 1 soğutucu, 1 bulaşık makinesi olmak üzere 9 makine kullanılmaktadir.

\subsection{Araştırma Yapılan Alakart Restoranın Üretim Prosesleri}

Araştırma yapılan konaklama işletmesinde alakart restoranın üretim süreçleri KTM yöntemine göre benzer faaliyetler aynı kaynak havuzunda toplanmak suretiyle hazırlı, pişirme ve sunum olmak üzere 3'e ayrılmıştır. Bu üretim süreçlerinde yapılan faaliyetler:

Hazırlık: Bu faaliyet yiyeceklerin pişirilecekse pişirilmeden önce, pişirilmeyecekse servis edilmeden önce yapılması gereken yıkama, ayıklama, soyma, kesme, doğrama, sıkma, ezme, marina etme, baharatlama, soslama vb. alt hazırlık faaliyetlerinden oluşmaktadır.

Pişirme: Bu faaliyet yiyeceklerin, kızartma, buğulama, haşlama, fırınlama vb. suretiyle pişirilip sunuma hazır hale getirildiği faaliyettir.

Sunum: Müşterilerin sipariş ettikleri yiyecekler gerek pişirilerek gerekse pişirilmeden tabaklarda sunuma hazır hale getirilerek servis edilmektedir.

\subsection{Araştırma Yapılan Alakart Restoranın Ăgustos 2019 Dönemine Ait Mönü Bilgileri}

Araştırma yapılan alakart restoranın Ağustos 2019 dönemiyle ilgili mönü bilgileri Tablo 1'de sunulmuştur.

Tablo 1. Alakart Restoran Ağustos 2019 Yemek Tüketim Miktarları (Porsiyon)

\begin{tabular}{|c|c|c|c|c|c|c|c|c|c|c|c|c|c|c|c|}
\hline \multirow{3}{*}{ 离 } & \multicolumn{15}{|c|}{ Yiyecek Grupları } \\
\hline & \multicolumn{3}{|c|}{ Çorbalar } & \multicolumn{3}{|c|}{ Mezeler } & \multicolumn{3}{|c|}{ Salatalar } & \multicolumn{3}{|c|}{ Ana Yemekler } & \multicolumn{3}{|c|}{ Tatlılar } \\
\hline & Ç1 & Ç2 & Ç3 & M1 & M2 & M3 & S1 & S2 & S3 & $\mathbf{A 1}$ & $\mathbf{A 2}$ & $\mathbf{A 3}$ & T1 & $\mathbf{T} 2$ & T3 \\
\hline 1 & 10 & 40 & 50 & 38 & 52 & 10 & 23 & 47 & 30 & 14 & 46 & 40 & 20 & 65 & 15 \\
\hline 2 & 35 & 25 & 40 & 62 & 28 & 10 & 55 & 10 & 35 & 44 & 42 & 14 & 36 & 46 & 18 \\
\hline 3 & 12 & 49 & 39 & 10 & 10 & 80 & 65 & 23 & 12 & 49 & 41 & 10 & 32 & 26 & 42 \\
\hline 4 & 51 & 28 & 21 & 5 & 67 & 28 & 20 & 26 & 54 & 46 & 10 & 44 & 44 & 22 & 34 \\
\hline 5 & 20 & 60 & 20 & 23 & 30 & 47 & 21 & 49 & 30 & 2 & 90 & 8 & 21 & 56 & 23 \\
\hline 6 & 15 & 65 & 20 & 32 & 38 & 30 & 15 & 5 & 80 & 69 & 21 & 10 & 9 & 40 & 51 \\
\hline 7 & 15 & 40 & 45 & 30 & 32 & 38 & 40 & 25 & 35 & 26 & 20 & 54 & 12 & 26 & 62 \\
\hline 8 & 90 & 5 & 5 & 45 & 5 & 50 & 54 & 16 & 30 & 65 & 23 & 12 & 10 & 17 & 73 \\
\hline 9 & 30 & 23 & 47 & 55 & 25 & 20 & 40 & 51 & 9 & 6 & 14 & 80 & 55 & 37 & 8 \\
\hline 10 & 46 & 10 & 44 & 2 & 18 & 80 & 60 & 25 & 15 & 30 & 23 & 47 & 42 & 53 & 5 \\
\hline 11 & 10 & 20 & 70 & 14 & 46 & 40 & 30 & 10 & 60 & 15 & 65 & 20 & 20 & 41 & 39 \\
\hline 12 & 20 & 30 & 50 & 9 & 51 & 40 & 46 & 10 & 44 & 51 & 28 & 21 & 12 & 24 & 64 \\
\hline 13 & 30 & 40 & 30 & 18 & 62 & 20 & 10 & 73 & 17 & 35 & 25 & 40 & 42 & 55 & 3 \\
\hline
\end{tabular}




\begin{tabular}{r|r|r|r|r|r|r|r|r|r|r|r|r|r|r|r}
\hline 14 & 40 & 50 & 10 & 63 & 17 & 20 & 2 & 90 & 8 & 23 & 30 & 47 & 45 & 36 & 19 \\
\hline 15 & 15 & 25 & 60 & 6 & 14 & 80 & 1 & 19 & 80 & 38 & 30 & 32 & 20 & 43 & 37 \\
\hline 16 & 25 & 35 & 40 & 26 & 20 & 54 & 4 & 7 & 89 & 55 & 35 & 10 & 62 & 12 & 26 \\
\hline 17 & 35 & 45 & 20 & 44 & 42 & 14 & 90 & 5 & 5 & 15 & 25 & 60 & 13 & 28 & 59 \\
\hline 18 & 45 & 50 & 5 & 67 & 23 & 10 & 81 & 17 & 2 & 30 & 20 & 50 & 7 & 22 & 71 \\
\hline 19 & 65 & 23 & 12 & 38 & 30 & 32 & 70 & 10 & 20 & 35 & 10 & 55 & 5 & 11 & 84 \\
\hline 20 & 15 & 30 & 55 & 51 & 47 & 2 & 69 & 21 & 10 & 65 & 23 & 12 & 65 & 35 & 0 \\
\hline 21 & 30 & 50 & 20 & 73 & 10 & 17 & 22 & 27 & 51 & 20 & 55 & 25 & 36 & 53 & 11 \\
\hline 22 & 35 & 10 & 55 & 49 & 41 & 10 & 65 & 15 & 20 & 51 & 27 & 22 & 23 & 34 & 43 \\
\hline 23 & 10 & 80 & 10 & 40 & 49 & 11 & 12 & 23 & 65 & 10 & 30 & 60 & 19 & 74 & 7 \\
\hline 24 & 60 & 15 & 25 & 69 & 21 & 10 & 8 & 11 & 81 & 25 & 35 & 40 & 47 & 44 & 9 \\
\hline 25 & 70 & 5 & 25 & 58 & 42 & 0 & 2 & 2 & 96 & 47 & 30 & 23 & 53 & 33 & 14 \\
\hline 26 & 2 & 90 & 8 & 73 & 27 & 0 & 63 & 5 & 32 & 47 & 1 & 52 & 72 & 10 & 18 \\
\hline 27 & 80 & 1 & 19 & 60 & 30 & 10 & 16 & 22 & 62 & 23 & 12 & 65 & 17 & 62 & 21 \\
\hline 28 & 4 & 7 & 89 & 55 & 35 & 10 & 9 & 81 & 10 & 20 & 54 & 26 & 33 & 40 & 27 \\
\hline 29 & 90 & 5 & 5 & 5 & 85 & 10 & 7 & 65 & 28 & 49 & 21 & 30 & 49 & 45 & 6 \\
\hline 30 & 81 & 2 & 17 & 30 & 20 & 50 & 25 & 26 & 49 & 80 & 5 & 15 & 5 & 44 & 51 \\
\hline 31 & 25 & 25 & 50 & 50 & 40 & 10 & 60 & 11 & 29 & 28 & 12 & 60 & 13 & 47 & 40 \\
\hline & & & & & & & & & & & & & & & \\
Toplam & $\mathbf{1 . 1 1 1}$ & $\mathbf{9 8 3}$ & $\mathbf{1 0 0 6}$ & $\mathbf{1 . 2 0 0}$ & $\mathbf{1 . 0 5 7}$ & $\mathbf{8 4 3}$ & $\mathbf{1 . 0 8 5}$ & $\mathbf{8 2 7}$ & $\mathbf{1 . 1 8 8}$ & $\mathbf{1 . 1 1 3}$ & $\mathbf{9 0 3}$ & $\mathbf{1 . 0 8 4}$ & $\mathbf{9 3 9}$ & $\mathbf{1 . 1 8 1}$ & $\mathbf{9 8 0}$ \\
& & & & & & & & & & & & & & & \\
\hline \hline
\end{tabular}

Tablo 1'de uygulama yapılan konaklama işletmesi alakart restoran aylık (Ağustos) tüketilen porsiyonlar gösterilmektedir. Tablo 1'e göre Ağustos ayında 1.111 porsiyon sebzeli enginar çorbası (Ç1), 983 porsiyon sütlü fesleğenli domates çorbası (Ç2), 1.006 porsiyon sebzeli tavuk çorbası olmak üzere 3.100 porsiyon çorba; 1.200 porsiyon havuçlu kerevizli meze (M1), 1.057 porsiyon tarator (M2), 843 porsiyon piyaz (M2) olmak üzere 3.100 porsiyon meze; 1.085 porsiyon Akdeniz salatas1 (S1), 827 porsiyon avokadolu domates salatas1 (S2), 1.188 porsiyon roka salatas1 (S3) olmak üzere 3.100 porsiyon salata; 1.113 porsiyon kremal1 mantar soslu biftek (A1), 903 porsiyon beşamel soslu patatesli tavuk (A2), 1.084 porsiyon firında çupra/levrek (A3) olmak üzere 3.100 porsiyon ana yemek ve 939 porsiyon tahinli kabak tatlıs1 (T1), 1.181 porsiyon sütlaç (T2), 980 porsiyon meyve (T3) olmak üzere 3.100 adet tatlı tüketilmiştir. 5 yemek grubundan toplamda 15.500 porsiyon Ağustos 2019 tüketim miktarını oluşturmaktadır. Alakart restoranda fiyat sabit olduğu için her yemek grubundan eşit miktarda tüketim söz konusudur.

\subsection{Ktm Uygulaması}

Şekil 4'te uygulama yapılan alakart restoranda KTM yönteminin uygulama süreci görülmektedir. 


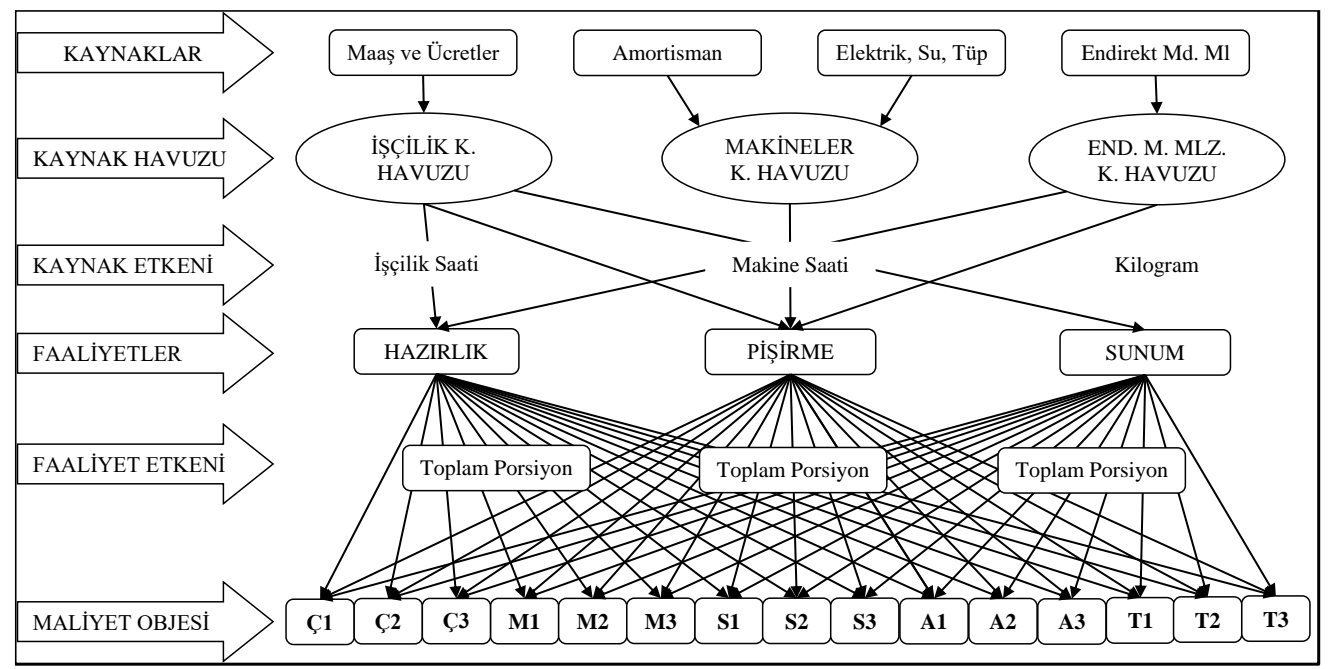

\section{Şekil 1. Konaklama İşletmesi Alakart Restoranında Kaynak Tüketim Muhasebesi Uygulama Süreci}

Şekil 4'te de görüldüğü üzere alakart restoranda bir akşam yemeği mönüsü üretmek için maaş ve ücretler, amortisman, elektrik-tüp-su ve endirekt madde ve malzemeler olmak üzere 4 grup kaynak kullanılmaktadır. Alakart restoranda KTM uygulamasında maaş ve ücretler işçilik kaynak havuzunda; amortisman, elektrik-tüp-su makineler tarafından tüketildiği için makineler kaynak havuzunda; endirekt madde ve malzemeler ise endirekt madde ve malzemeler kaynak havuzunda toplanmıştır. İşçilik kaynak havuzunda toplanan maliyetler işçilik saati; makineler kaynak havuzunda toplanan maliyetler makine saati ve endirekt madde ve malzeme kaynak havuzunda toplanan maliyetler kilogram kaynak etkeni (dağıtım anahtarı) kullanılarak faaliyetlere dağıtılmıştır. Konaklama işletmesinin alakart restoranında gerçekleştirilen faaliyetler (gider yerleri) ise hazırlık, pişirme ve sunumdur. Bu faaliyetlerde toplanan maliyetleri maliyet objelerine diğer bir ifadeyle yiyeceklere dağıtırken kullanılacak faaliyet etkeni (dağıtım anahtarı) her üç faaliyet için de üretim miktarıdır.

Tablo 2. 2019/A ğustos Ayı Genel Üretim Giderleri

\begin{tabular}{lc}
\hline \hline Maaş ve Ücretler & $60.300 \mathrm{TL}$ \\
\hline Amortisman & $3.000 \mathrm{TL}$ \\
\hline Elektrik & $2.800 \mathrm{TL}$ \\
\hline Tüp & $3.100 \mathrm{TL}$ \\
\hline Su & $3.200 \mathrm{TL}$ \\
\hline Endirekt Madde ve Malzeme & $11.500 \mathrm{TL}$ \\
\hline Toplam & $\mathbf{8 3 . 9 0 0 ~ T L}$ \\
\hline \hline
\end{tabular}


Tablo 2'de uygulama yapılan alakart restoranın 2019 ağustos ayına ait genel üretim giderleri (GÜG) gösterilmektedir. Buna göre 2019 Ağustos ayına ait toplam 83.900 TL genel üretim gideri bulunmaktadır.

Tablo 3. Kaynak Havuzlarına Göre Sabit ve Değișken Maliyetler

\begin{tabular}{lrrrr}
\hline \hline \multicolumn{1}{c}{ Kaynak Havuzu } & Toplam Maliyet & Sabit Maliyet & $\begin{array}{c}\text { Değişken } \\
\text { Maliyet }\end{array}$ & Kaynak Etkeni \\
\hline İşçilik & 60.300 & 9.000 & 51.300 & İşçilik Saati \\
\hline Makineler & 12.100 & 3.000 & 9.100 & Makine Saati \\
\hline Endirekt Malzeme & 11.500 & - & 11.500 & Kilogram \\
\hline Toplam & $\mathbf{8 3 . 9 0 0 ~ T L}$ & & & \\
\hline \hline
\end{tabular}

Tablo 3'te işletmenin kaynak havuzları, kaynak havuzlarının sabit ve orantısal (değişken) maliyetleri ile birlikte toplam maliyetleri ve bu maliyetleri faaliyetlere dağıtmada kullanılacak kaynak etkenleri (dağıtım anahtarları) gösterilmektedir. Kaynak havuzlarında bulunan maliyetlerin sabit ve değişken maliyeti aşağıdaki şekilde hesaplanmıştır:

Isçcilik Kaynak Havuzu: Konaklama işletmesinin alakart restoranında 6 aşçı, 3 yamak, 6 garson, 3 komi, 1 bulaşıkçı olmak üzere 19 direkt işçi çalışmaktadır. Bu direkt işçiliklerin brüt ücretleri toplamı değişken gider olarak alınmıştır. Ayrıca restoranda çalışan 1 restoran şefi ve 1 mutfak şefinin brüt ücretleri (üretime doğrudan katılmadıkları ve endirekt işçilik sayıldığı için) sabit gider olarak alınmıştır. Maliyet muhasebesinde ve yöntemde direkt işçilik giderleri üretim hacmi ile doğru orantılı olduğu için direkt işçilikler yani üretimde çalışan işçilerin ücretleri değişken gider olarak, şef, müdür, aşçıbaşı, kalfa gibi doğrudan üretime katılmayan endirekt işçilikler ise üretim hacminden bağımsız giderler olduğu için sabit gider olarak alınmıştır

Makineler Kaynak Havuzu: Üretimde kullanılan makinelerin amortismanı sabit gider olarak; üretim makinelerinde kullanılan elektrik, tüp ve su giderleri ise değişken gider olarak alınmıştır.

Endirekt Madde ve Malzeme Kaynak Havuzu: Akşam yemeğinde kullanılan endirekt madde ve malzemeler üretim ile doğru orantılı olarak artmaktadır. Bu nedenle endirekt madde ve malzeme giderleri değişken maliyet olarak alınmıştır.

Tablo 4. Kaynak Havuzlarının Teorik ve Pratik Kapasiteleri ve Oranları

\begin{tabular}{lrrrrr}
\hline \hline \multicolumn{1}{c}{ Kaynak Havuzu } & $\begin{array}{c}\text { Teorik } \\
\text { Kapasite }\end{array}$ & $\begin{array}{c}\text { Pratik } \\
\text { Kapasite }\end{array}$ & $\begin{array}{c}\text { Sabit Maliyet } \\
\text { Oranı }\end{array}$ & $\begin{array}{c}\text { Değişken Maliyet } \\
\text { Oranı }\end{array}$ \\
\hline İşçilik & 5.040 & 4.368 & 1,78 & 11,74 \\
\hline Makineler & 720 & 345 & 4,16 & 26,37 \\
\hline Endirekt Malzeme & - & 580 & - & 19,82 \\
\hline \hline
\end{tabular}

Tablo 4'te işletmenin kaynak havuzlarının teorik ve pratik kapasiteleri ile sabit maliyet ve değişken maliyet oranları görülmektedir. KTM, sabit maliyetlerin teorik kapasiteye göre olması gerektiğini savunmaktadır. Örneğin bir makinanın teorik kapasitesi makinanın 30 gün 24 saat kesintisiz çalışması durumunu ifade ederken; pratik kapasitesi üretimde aktif olduğu 
gün ve saati ifade etmektedir (Okutmuş, 2015: 53). Buna göre uygulama yapılan işletmenin alakart restoranının teorik ve pratik kapasite hesaplamaları aşağıdaki gibidir:

Isşcilik Kaynak Havuzu: Normal standartlara göre bir işçinin günde 8 saat üzerinden 30 gün çalıştığı varsayıldığında 21 işçinin teorik kapasitesi 5.040 işçilik saati olarak hesaplanmaktadır. Ancak uygulama yapılan işletmede bir ayda bir işçi 26 gün çalışmaktadır. Buna göre 21 işçinin günde 8 saat ve aylık 26 gün üzerinden pratik kapasitesi 4.368 işçilik saati olarak hesaplanmıştır.

Teorik Kapasite $=$ Bir İşçinin Günlük Çalışma Saati * 30 Gün * Toplam İşçi Sayısı $=8 * 30 * 21$

$=5.040$ İşçilik Saati

Pratik Kapasite $=$ Bir İşçinin Günlük Çalışma Saati * 26 Gün * Toplam İşçi Sayısı

$$
\begin{aligned}
& =8 * 26 * 21 \\
& =4.368 \text { İşçilik Saati }
\end{aligned}
$$

Makineler Kaynak Havuzu ${ }^{4}$ : Bir makinenin hiç ara vermeden 24 saat çalıştı̆̆1 düşünüldüğünde işletmenin teorik kapasitesi 24 saat $* 30$ gün $=720$ makine saati olarak belirlenecektir. Uygulama yapılan alakart restoranda bir günde en fazla 100 kişi ağırlanmakta dolayısıyla 100 adet 5 gruptan oluşan akşam yemeği sunulabilmektedir. Her bir yiyeceğin üretim süresi farklı olmakla birlikte çalışmada en uzun sürede hazırlanan beşamel soslu patatesli tavuk yemeğinin üretim süresi olan 62 dakika baz alınmıştır. Buna göre makineler kaynak havuzunun pratik kapasitesi şu şekilde hesaplanmıştır:

Makineler Pratik Kapasitesi $=100 * 62$ dakika $=6.200$ dakika günlük

$$
\begin{aligned}
& =6.200 * 30 \text { gün }=186.000 \text { dakika aylık } \\
& =186.000 / 60=3.100 \text { saat } \\
& =3.100 / 9 \text { makine }=345 \text { saat }
\end{aligned}
$$

Endirekt Madde ve Malzeme Kaynak Havuzu: Endirekt madde ve malzemeler doğrudan akşam yemeği üretimi ile ilgili olduğu için bu kaynak havuzunun teorik kapasitesi bulunmamaktadır. Pratik kapasitesi ise Alakart restoranda kullanılan kişniş 4,13 kg, nar ekşisi $22,73 \mathrm{~kg}$, tuz $23,81 \mathrm{~kg}$, zeytinyağ $119,17 \mathrm{~kg}$, çiçek yağ1 $6 \mathrm{~kg}$, tereyağ1 $29,87 \mathrm{~kg}$, sarımsak $18,17 \mathrm{~kg}$, un $27,59 \mathrm{~kg}$, domates salças $4 \mathrm{~kg}$, karabiber $20,07 \mathrm{~kg}$, pul biber 11,19 kg, kekik $9,03 \mathrm{~kg}$, kimyon $2,16 \mathrm{~kg}$, defne yaprağ $10,84 \mathrm{~kg}$, toz fesleğen $3 \mathrm{~kg}$, krema $5 \mathrm{~kg}$, sirke 50,58 $\mathrm{kg}$, ceviz içi $75,12 \mathrm{~kg}$, tahin $56,34 \mathrm{~kg}$, pirinç unu 7,08 kg, nişasta 5,9 kg, pirinç 11,81 kg, şeker 7,91 kg, maydanoz $25,29 \mathrm{~kg}$, marul $12,36 \mathrm{~kg}$ ve lolorosso $10,85 \mathrm{~kg}$ olmak üzere toplam $580 \mathrm{~kg}$ endirekt madde ve malzemedir.

\footnotetext{
${ }^{4}$ Makineler kaynak havuzunun pratik kapasitesi belirlenirken söz konusu ürün/ürünlerin birbirleriyle benzer olan üretim süresi kullanılmaktadır. Ancak çalışmada yer alan ürünlerin her birinin üretim süresi farklılık göstermektedir. $\mathrm{Bu}$ nedenle çalışmada üretim süresi olarak en uzun sürede $(25 \mathrm{dk}$ hazırlık, $35 \mathrm{dk}$ pişirme, $2 \mathrm{dk}$ sunum olmak üzere toplam $62 \mathrm{dk}$ ) üretilen beşamel soslu patatesli tavuk yemeğinin süresi dikkate alınmıştır. Böylece söz konusu sürede müşterilerin istediği diğer yiyeceklerde hazır hale getirilebilmektedir.
} 
Tablo 4'te ayrıca sabit maliyetlerin teorik kapasiteye; değişken maliyetlerin ise pratik kapasiteye göre oranları da gösterilmektedir. Bu oranlar aşağıdaki şekilde hesaplanmıştır:

$$
\begin{aligned}
& \text { İşçilik Sabit Maliyet Oranı }=\frac{\text { İşçilik Sabit Maliyeti (Tablo 3) }}{\text { Isş̧ilik Teorik Kapasitesi (Tablo 4) }} \\
& \text { İşçilik Sabit Maliyet Oranı }=\frac{9.000}{5.040}=1.78 \\
& \text { İşçilik Değișken Maliyet Oramı }=\frac{\text { İșçilik Değișken Maliyeti (Tablo 3) }}{\text { Issçilik Pratik Kapasitesi (Tablo 4) }} \\
& \text { İşçilik Değișken Maliyet Oramı }=\frac{51.300}{4.368}=11,74 \\
& \text { Makineler Sabit Maliyet Oranı }=\frac{\text { Makineler Sabit Maliyeti (Tablo 3) }}{\text { Makineler Teorik Kapasitesi (Tablo 4) }} \\
& \text { Makineler Sabit Maliyet Oramı }=\frac{3.000}{720}=4,16 \\
& \text { Makineler Değișken Maliyet Oranı }=\frac{\text { Makineler Değișken Maliyeti (Tablo 3) }}{\text { Makineler Pratik Kapasitesi (Tablo 4) }} \\
& \text { Makineler Değișken Maliyet Oranı }=\frac{9.100}{345}=26,37 \\
& \text { End.Mad. Mlz.Değişken Maliyet Oranı }=\frac{\text { End. Mad. Mlz. Değișken Maliyeti (Tablo 3) }}{\text { End. Mad. Mlz. Pratik Kapasitesi (Tablo 4) }} \\
& \text { End.Mad. Mlz.Değişken Maliyet Oramı }=\frac{11.500}{580}=19,82
\end{aligned}
$$

Tablo 5. Havuzlardan Faaliyetlerin Tükettiği Kaynaklar

\begin{tabular}{lrrrr}
\hline \multicolumn{1}{c}{ Kaynak Havuzu } & Hazırlık & \multicolumn{1}{c}{ Pişirme } & \multicolumn{1}{c}{ Sunum } & \multicolumn{1}{c}{ Toplam } \\
\hline İş̧ilik (İ. saat) & 624 & 1664 & 2.080 & 4.368 \\
\hline Makineler (m. saat) & - & 345 & - & 345 \\
\hline End. Mlz. (kg) & 131,47 & 448,53 & - & 580 \\
\hline \hline
\end{tabular}

Tablo 5'te kaynak havuzlarından faaliyetlerin tükettiği kaynaklar (pratik kapasiteleri-Tablo 4) ayrıntılı bir şekilde gösterilmiştir. Hesaplamalar aşağıdaki şekilde yapılmıştır:

Hazırık Gider Yeri İşçilik Pratik Kapasitesi = (İşçilik Pratik Kapasitesi (Tablo 4) / Toplam İşçi Sayıs1 $\left.{ }^{5}\right)$ * Hazırlık Gider Yeri İşçi Sayısı

$$
\begin{aligned}
& =(4.368 / 21) * 3 \\
& =624
\end{aligned}
$$

\footnotetext{
5 Alakart restoranda 1 aşçı ve 2 yamak hazırlık faaliyetinde; 5 aşçı, 1 yamak, 1 bulaşıkçı ve 1 mutfak şefi pişirme faaliyetinde; 6 garson, 3 komi ve 1 restoran şefi sunum faaliyetinde olmak üzere toplam 21 personel çalışmaktadır.
} 
Pişirme Gider Yeri İşçilik Pratik Kapasitesi = (İşçilik Pratik Kapasitesi (Tablo 4) / Toplam İşçi Sayısı) * Pişirme Gider Yeri İşçi Sayısı

$$
\begin{aligned}
& =(4.368 / 21) * 8 \\
& =1.664
\end{aligned}
$$

Sunum Gider Yeri İşçilik Pratik Kapasitesi= (İşçilik Pratik Kapasitesi (Tablo 4) / Toplam İşçi Sayısı) * Sunum Gider Yeri İşçi Sayısı

$$
\begin{aligned}
& =(4.368 / 21) * 10 \\
& =2.080
\end{aligned}
$$

Hazırlık Gider Yeri Makineler Pratik Kapasitesi= (Makineler Pratik Kapasitesi (Tablo 4) / Toplam Makine Saati ${ }^{6}$ * Hazırlık Gider Yeri Makine Saati

$$
=(345 / 35) * 0=0
$$

Pişirme Gider Yeri Makineler Pratik Kapasitesi = (Makineler Pratik Kapasitesi (Tablo 4) / Toplam Makine Saati) * Pişirme Gider Yeri Makine Saati

$$
\begin{aligned}
& =(345 / 35) * 35 \\
& =345
\end{aligned}
$$

Sunum Gider Yeri Makineler Pratik Kapasitesi= (Makineler Pratik Kapasitesi (Tablo 4) / Toplam Makine Sayısı) * Sunum Gider Yeri Makine Sayısı

$$
=(345 / 35) * 0=0
$$

Hazırlık Gider Yeri Endirekt Madde ve Malzeme Pratik Kapasitesi: $\mathrm{Bu}$ gider yerini endirekt madde ve malzeme pratik kapasitesi, pişirilmeden hazırlanan havuçlu kerevizli meze, tarator, Akdeniz salata, avokadolu domates salatası ve roka salatasında kullanılan endirekt madde ve malzemelerin ağustos ayı kullanım miktarı olan 131,47 kg'dır. Söz konusu yiyeceklere ağustos ayında 12,36 kg marul, 10,85 kg lolorosso, 63,12 kg zeytinyağ1, 22,73 kg nar ekşisi, 5,93 kg tuz, 3,82 kg karabiber, 4,13 kg kişniş ve 8,53 kg sarımsak olmak üzere toplam 131,47 kg endirekt madde ve malzeme kullanılmıştır.

Pişirme Gider Yeri Endirekt Madde ve Malzeme Pratik Kapasitesi: Bu gider yerinde mönüde yer alan ve pişirilerek hazırlanan yiyeceklerde kullanılan endirekt madde ve malzemelerin ağustos ayı kullanım miktarı olan 448,53 kg endirekt madde ve malzeme pratik kapasitesi olarak hesaplanmıştır. $\mathrm{Bu}$ en direkt madde ve malzemeler ise kişniş tuz 17,88 kg, zeytinyağı $56,05 \mathrm{~kg}$, çiçek yağı $6 \mathrm{~kg}$, tereyağ1 $29,87 \mathrm{~kg}$, sarımsak $9,64 \mathrm{~kg}$, un $27,59 \mathrm{~kg}$, domates salçası $4 \mathrm{~kg}$, karabiber 16,25 kg, pul biber 11,19 kg, kekik 9,03 kg, kimyon 2,16 kg, defne yaprağ $110,84 \mathrm{~kg}$, toz fesleğen $3 \mathrm{~kg}$, krema $5 \mathrm{~kg}$, sirke $50,58 \mathrm{~kg}$, ceviz içi 75,12 kg, tahin $56,34 \mathrm{~kg}$, pirinç unu 7,08 kg, nişasta $5,9 \mathrm{~kg}$, pirinç $11,81 \mathrm{~kg}$, şeker 7,91 kg, maydanoz $25,29 \mathrm{~kg}$, olmak üzere toplam 448,53 kg'dır.

\footnotetext{
${ }^{6}$ Konaklama işletmesi alakart restoran KTM uygulamasında makineler kaynak havuzunda yer alan makineler sadece pişirme faaliyetinde kullanılmaktadır. Pişirme faaliyetini en çok kullanan ürün/yemek ise 35 dakika pişirme süresi ile beşamel soslu patatesli tavuk yemeğidir. Dolayıssıla toplam makine saati pişirme faaliyetinde geçen 35 dakika olup diğer faaliyetlerde makine kullanılmadığı için 0'dır. Diğer bir ifadeyle makineler kaynağını sadece pişırme faaliyeti tüketmekte ve pişirme faaliyetinin makineler pratik kapasitesi bulunmaktadır. 
Sunum Gider Yeri Endirekt Madde ve Malzeme Pratik Kapasitesi: Bu gider yerinde endirekt madde ve malzeme kullanılmamaktadır.

Tablo 6. Kaynak Havuzlarındaki Maliyetlerin Faaliyetlere Dağıtımı

\begin{tabular}{lrrrr}
\hline \multicolumn{1}{c}{ Kaynak Havuzu } & \multicolumn{1}{c}{ Hazırlık } & \multicolumn{1}{c}{ Pişirme } & \multicolumn{1}{c}{ Sunum } & \multicolumn{1}{c}{ Toplam } \\
\hline İşçilik (İ. saat) & $8.436,48$ & $22.497,28$ & $28.121,6$ & $59.055,36$ \\
\hline Makineler (m. saat) & - & $10.532,85$ & - & $10.532,85$ \\
\hline End. Mlz. (kg) & $2.605,73$ & $8.889,86$ & & $11.495,59$ \\
\hline Toplam & $\mathbf{1 1 . 0 4 2 , 2 1}$ & $\mathbf{4 1 . 9 1 9 , 9 9}$ & $\mathbf{2 8 . 1 2 1 , 6}$ & $\mathbf{8 1 . 0 8 3 , 8}$ \\
\hline \hline
\end{tabular}

Tablo 6'da KTM yöntemine göre kaynak havuzlarında toplanan maliyetlerin faaliyetlere (gider yerlerine) dağıtımı gösterilmektedir. Tablo 5'te de görüldüğü üzere hazırlık faaliyetine 11.042,21 TL; pişirme faaliyetine 41.919,99 TL ve sunum gider yerine 28.121,6 TL olmak üzere toplam 81.083,8 TL dağıtılmıştır. Hesaplamalar aşağıdaki şekilde yapılmıştır:

İşçilik Kaynak Havuzu Maliyetlerinin Hazırık Faaliyetine Dağıtımı: Hazırlık Gider Yeri İşçilik Saati (Tablo 5) * Sabit Maliyet İşçilik Oranı (Tablo 4) + Hazırlık Gider Yeri İşçilik Saati (Tablo 5) * Değişken Maliyet İşçilik Oranı $($ Tablo 4) $=(624 * 1,78)+(624 * 11,74)=$ $1.110,72+7.325,76=8.436,48$

İşçilik Kaynak Havuzunun Pişirme Faaliyetine Dağıtımı: (Pişirme Gider Yeri İşçilik Saati * Sabit Maliyet İşçilik Oranı) + (Pişirme Gider Yeri İşçilik Saati * Değişken Maliyet İşçilik Oran1 $)=(1.664 * 1,78)+(1.664 * 11,74)=2.961,92+19.535,36=22.497,28$

İşçilik Kaynak Havuzunun Sunum Faaliyetine Dağıtımı: (Sunum Gider Yeri İşçilik Saati * Sabit Maliyet İşçilik Oranı) + (Sunum Gider Yeri İşçilik Saati * Değişken Maliyet İşçilik Oran1 $)=(2.080 * 1,78)+(2.080 * 11,74)=3.702,4+24.419,2=28.121,6$

Makineler Kaynak Havuzunun Hazırlık Gider Yerine Dağıtımı: Hazırlık gider yerinde makineler kaynak havuzunda yer alan makineler kullanılmadığı için hazırlık faaliyeti makineler kaynak havuzundan pay almamaktadır.

Makineler Kaynak Havuzunun Pişirme Gider Yerine Dağıtımı: (Pişirme Gider Yeri Makine Saati * Sabit Maliyet Makineler Oran1) + (Pişirme Gider Yeri Makine Saati * Değişken Maliyet Makineler Oranı $)=(345 * 4,16)+(345 * 26,37)=1.435,2+9.907,65=$ $10.532,85$

Makineler Kaynak Havuzunun Sunum Gider Yerine Dağıtımı: Sunum gider yerinde makineler kaynak havuzunda yer alan makineler kullanılmadığı için sunum faaliyeti makineler kaynak havuzundan pay almamaktadır.

Endirekt Madde ve Malzeme Kaynak Havuzu Maliyetlerinin Hazırlık Gider Yerine Dağıtımı: (Hazırlık Gider Yeri Toplam Endirekt Madde Malzeme Kilogramı*Sabit Maliyet Endirekt Madde ve Malzeme Oranı) + (Hazırlık Gider Yeri Endirekt Madde Malzeme Kilogramı * Değişken Maliyet Endirekt Madde ve Malzeme Oranı) $=(131,47 * 0)+(131,47$ $* 19,82)=2.605,73$

Endirekt Madde ve Malzeme Kaynak Havuzu Maliyetlerinin Pişirme Gider Yerine Dağıtımı: (Pişirme Gider Yeri Toplam Endirekt Madde Malzeme Kilogramı*Sabit Maliyet 
Endirekt Madde ve Malzeme Oranı) + (Pişirme Gider Yeri Endirekt Madde Malzeme Kilogramı * Değişken Maliyet Endirekt Madde ve Malzeme Oranı $)=(448,53 * 0)+(448,53$ $* 19,82)=8.889,86$

Tablo 7. Faaliyetler ve Tükettiği Kaynaklar

\begin{tabular}{|c|c|c|c|}
\hline Faaliyetler & Hazırlık & Pişirme & Sunum \\
\hline Yükleme Oranları & 0,71 & 2,70 & 1,81 \\
\hline Faaliyet Etkeni & \multicolumn{3}{|c|}{ Porsiyon (Üretim Miktarı) } \\
\hline Çorba 1 & & & 1.111 \\
\hline Çorba 2 & & & 983 \\
\hline Çorba 3 & & & 1.006 \\
\hline Meze 1 & & & 1.200 \\
\hline Meze 2 & & & 1.057 \\
\hline Meze 3 & & & 843 \\
\hline Salata 1 & & & 1.085 \\
\hline Salata 2 & & & 827 \\
\hline Salata 3 & & & 1.188 \\
\hline Ana Yemek 1 & & & 1.113 \\
\hline Ana Yemek 2 & & & 903 \\
\hline Ana Yemek 3 & & & 1.084 \\
\hline Tatl1 1 & & & 939 \\
\hline Tatl1 2 & & & 1.181 \\
\hline Tatli 3 & & & 980 \\
\hline Toplam & & & 15.500 \\
\hline
\end{tabular}

Tablo 7'de alakart restoranda yapılan faaliyetler ve faaliyet maliyetlerini ürünlere yüklemede kullanılacak faaliyet etkenleri (dağıtım anahtarları) ve yükleme oranları gösterilmektedir. Hazırlık, pişirme ve sunum faaliyetlerinde toplanan maliyetleri ürünlere yüklemede kullanılacak faaliyet etkeni ağustos ayında üretilen toplam porsiyon miktarı olup Tablo 7'de mönüde yer alan yiyeceklerin aylık tüketim miktarları (porsiyon) da yer almaktadır. Yükleme oranları, hazırlık, pişirme ve sunum bölümlerinde 2019 Ağustos ayı toplam üretilen porsiyon miktarı olan 15.500 adet faaliyet etkeni (dağıtım anahtarı) alınarak faaliyet havuzlarında toplanan maliyetlere (Tablo 6) bölünmesi ile aşağıdaki şekilde hesaplanmıştır:

Hazırıı Faaliyeti Yükleme Oranı = Hazırlık Faaliyeti Toplam Maliyeti (Tablo 6) / Toplam Üretim

$$
\begin{aligned}
& =11.042,21 / 15.500 \\
& =0,71240065
\end{aligned}
$$


Pişirme Faaliyeti Yükleme Oranı = Pişirme Faaliyeti Toplam Maliyeti (Tablo 6) / Toplam Üretim

$$
\begin{aligned}
& =41.919,99 / 15.500 \\
& =2,70451548
\end{aligned}
$$

Sunum Faaliyeti Yükleme Oranı = Sunum Faaliyeti Toplam Maliyeti (Tablo 6) $/$ Toplam Üretim

$$
\begin{aligned}
& =28.121,6 / 15.500 \\
& =1,81429677
\end{aligned}
$$

\begin{tabular}{|c|c|c|c|c|}
\hline Faaliyetler & Hazırlık & Pişirme & Sunum & \\
\hline Yükleme Oranları & 0,71 & 2,70 & 1,81 & Toplam \\
\hline \multicolumn{5}{|l|}{ Ürünler } \\
\hline Çorba 1 & 791,47 & $3.004,71$ & $2.015,68$ & $5.811,86$ \\
\hline Çorba 2 & 700,28 & $2.658,53$ & $1.783,45$ & $5.142,26$ \\
\hline Çorba 3 & 716,67 & $2.720,74$ & $1.825,18$ & $5.262,59$ \\
\hline Meze 1 & 854,88 & $3.245,49$ & $2.177,15$ & $6.277,52$ \\
\hline Meze 2 & 753,00 & $2.858,67$ & $1.917,71$ & $5.529,38$ \\
\hline Meze 3 & 601,00 & $2.279,90$ & $1.529,45$ & $4.410,35$ \\
\hline Salata 1 & 772,41 & $2.934,39$ & $1.968,51$ & $5.675,31$ \\
\hline Salata 2 & 589,15 & $2.236,63$ & $1.500,42$ & $4.326,20$ \\
\hline Salata 3 & 846,33 & $3.212,96$ & $2.155,38$ & $6.214,67$ \\
\hline Ana Yemek 1 & 793,00 & $3.010,12$ & $2.019,31$ & $5.822,43$ \\
\hline Ana Yemek 2 & 643,29 & $2.442,17$ & $1.638,30$ & $4.723,76$ \\
\hline Ana Yemek 3 & 772,24 & $2.931,69$ & $1.966,69$ & $5.670,62$ \\
\hline Tatlı 1 & 669,00 & $2.539,54$ & $1.703,59$ & $4.912,13$ \\
\hline Tatl1 2 & 841,34 & $3.194,03$ & $2.142,68$ & $6.178,05$ \\
\hline Tatlı 3 & 698,15 & $2.650,42$ & $1.778,10$ & $5.126,67$ \\
\hline Toplam & $11.042,21$ & $41.919,99$ & $28.121,60$ & $81.083,80$ \\
\hline
\end{tabular}

Tablo 8. Faaliyet Havuzlarında Toplanan Maliyetlerin Yiyeceklere Dağıtımı

Tablo 8'de faaliyet havuzlarında toplanan maliyetlerin maliyet objesine (ürünlere/yiyeceklere) dağıtımı görülmektedir. Tablo 8 'de de görüldüğü üzere hazırlık, pişirme ve sunum faaliyetlerinde toplanan maliyetler yükleme oranları aracılığıyla mönüde yer alan 15 adet yiyeceğe dağıtılmıştır. Hesaplamalar ise her yemek gurubundan birer örnek vererek aşağıdaki şekilde yapılmıştır:

$\begin{aligned} \text { Hazırıı F. Maliyetlerinin } & =\begin{array}{l}\text { Hazırlık Yükleme Oranı* Ç1 Toplam Porsiyon } \\ \text { Çorba 1'e Dağıtımı }\end{array} \\ & =0,71 * 1.111=791,47\end{aligned}$ 


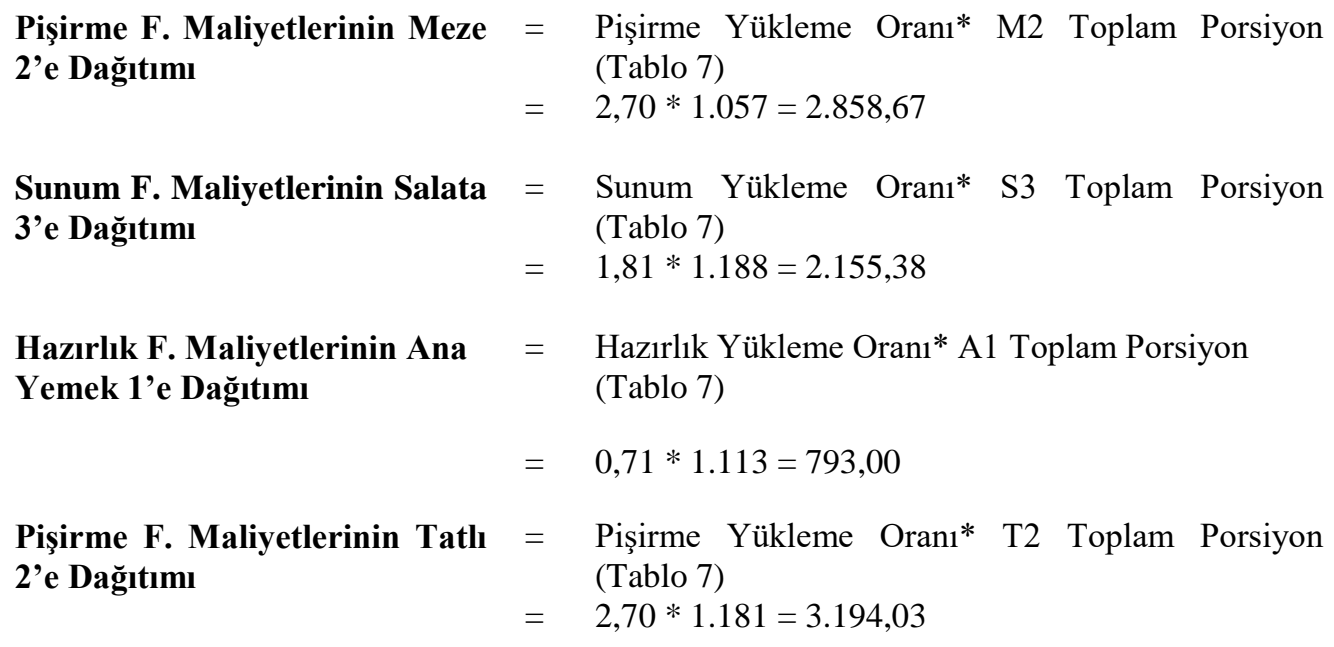

Tablo 9. KTM Atıl Kapasite Maliyetleri

\begin{tabular}{lcrr}
\hline \hline \multicolumn{1}{c}{ Kaynak Havuzu } & $\begin{array}{l}\text { Katlanılan } \\
\text { Maliyetler }\end{array}$ & $\begin{array}{l}\text { Dağıtılan } \\
\text { Maliyetler }\end{array}$ & \multicolumn{1}{c}{$\begin{array}{c}\text { Atıl Kapasite } \\
\text { Maliyeti }\end{array}$} \\
\hline İşçilik & 60.300 & $59.055,36$ & $1.244,64$ \\
\hline Makineler & 12.100 & $10.532,85$ & $1.567,15$ \\
\hline Endirekt Malzeme & 11.500 & $11.495,59$ & 4,41 \\
\hline Toplam & $\mathbf{8 3 . 9 0 0}$ & $\mathbf{8 1 . 0 8 3 , 8}$ & $\mathbf{2 . 8 1 6 , 2 0}$ \\
\hline \hline
\end{tabular}

Tablo 9'da uygulama yapılan konaklama işletmesinin alakart restoranında kaynak tüketim muhasebesi uygulaması sonucu ortaya çıkan atıl kapasite gösterilmektedir. KTM'de bir işletmenin katlandığı maliyetlerden (Tablo 2) dağıtılan maliyetlerin (Tablo 6) çıkarılması sonucu atıl kapasiteye ulaşılmaktadır. Tablo 8'de de görüldüğü üzere işçilik kaynak havuzunda 1.244,64 TL, makineler kaynak havuzunda 1.567,15 TL ve endirekt madde ve malzeme kaynak havuzunda 4,41 TL olmak üzere toplam 2.816,20 TL atıl kapasite saptanmıştır. KTM'ye göre bu maliyetler ürünlere dağıtılmayarak kaynak havuzlarında bırakılmış diğer bir ifadeyle dönem gideri olarak alınmıştır.

\section{SONUÇ}

Dünya genelinde yaşanan küreselleşme, rekabetin yoğunlaşarak küresel bir boyut kazanması, teknolojik gelişmeler ve bunun üretim ortamlarına yansıması, ürün çeşitliliğin artması ve ürün yaşam dönemlerinin kısalması gibi nedenler diğer tüm işletmelerde olduğu gibi konaklama işletmelerinde de geleneksel maliyet yöntemlerinin yetersiz kalmasına neden olmuştur. Teknolojik gelişmeler, direkt işçilik giderlerinin toplam üretim maliyetleri içindeki payı azalmasına genel üretim giderlerinin payının artmasına neden olmuştur. Bu gelişmeler, aynı zamanda küresel bir ortamda faaliyet gösteren konaklama işletmelerinde fiyatın piyasada, karın ortaklar tarafından belirleniyor olması nedeniyle işletmenin kontrol edebileceği tek 
değişkenin maliyet ile sonuçlanmasına neden olmuştur. Konaklama işletmeleri de yoğun rekabet ortamında ve değişen bu koşullar karşısında yetersiz kalan geleneksel maliyet yöntemleri yerine alternatif çağdaş maliyet yöntem ve teknikleri arayışına girmiştir. $\mathrm{Bu}$ yöntemlerden biri de işletmeyi kaynak temelli ele alan, tüketilen kaynaklar ile bu kaynakların maliyetlerini detaylı bir şekilde analiz eden bir yönetim ve maliyet muhasebesi aracı olan kaynak tüketim muhasebesidir.

İşletmelere maliyet bilgileri konusunda daha sağlıklı ve faydalı bilgiler vermesi ve dolayısıyla maliyet yönetimi ve kapasite kontrolü sağlaması açısından KTM yöntemini uygulanabilirliği denemek amacıyla Antalya'da faaliyet gösteren beş yıldızlı bir konaklama işletmesinin alakart restoranında araştırmanın uygulaması gerçekleştirilmiştir. Uygulama sonucunda aşağıdaki bulgulara ulaşılmıştır:

Uygulama yapılan konaklama işletmesinin alakart restoranında 2019 Ağustos ayında 5 ana yemek grubundan olmak üzere 15 çeşit yemek üretilmektedir. Yemek üretimi için gerçekleştirilen faaliyetler hazırlık, pişirme ve sunum olmak üzere 3 ana başlık altında toplanmıştır. Yemek üretiminde kullanılan kaynaklar ve kaynak havuzları belirlendikten sonra kaynak havuzlarında toplanan maliyetleri faaliyetlere yüklemede kullanılacak kaynak etkenleri, faaliyetlerde toplanan maliyetleri maliyet objelerine (yemeklere) yüklemede kullanılacak faaliyet etkenleri belirlenmiştir.

Alakart restoranın kaynak havuzlarında toplanan maliyetler sabit ve değişken (orantısal) olmak üzere ayrılmış, bu maliyetleri faaliyetlere dağıtmak için restoranın teorik ve pratik kapasiteleri belirlenmiş ve kaynak havuzlarında toplanan maliyetler bu değişkenler aracılığıyla faaliyetlere dağıtılmıştır. Faaliyetlerde toplanan maliyetler ise aylık toplam porsiyon faaliyet etkeni alınarak ürünlere/yemeklere yüklenmiştir.

Elde edilen bulgulara göre konaklama işletmesinin alakart restoranında 2019 Ağustos ayında katlanılan maliyetler $83.900 \mathrm{TL}$ iken ürünlere/yemeklere dağıtılan maliyet 81.083,8 TL'dir. Katlanılan maliyet ile dağıtılan maliyet arasındaki farkı ifade eden 2.816, 20 TL ise atıl kapasite olarak belirlenmiştir. İşçilik kaynak havuzunda 1.244,64TL, makineler kaynak havuzunda 1.567,15 TL, endirekt madde ve malzeme kaynak havuzunda 4,41 TL olmak üzere 2,816,20TL atıl kapasite ürünlere/yemeklere dağıtılmayarak dönem gideri olarak alınmıştır. Diğer bir ifadeyle ürünler/yemekler tüketmedikleri kaynaklardan pay almamış böylece daha doğru maliyet verisi sağlanmıştır.

KTM yönteminin en önemli özelliği atıl kapasitenin belirlenerek kontrol ve yönetimini sağlamasıdır. Böylece işletmede yöneticilerin daha doğru maliyet verileri ile karar alma sürecine destek olmakta ve işletmenin etkinliği ve verimliliğine katkı sağlamaktadır. Yönetim kararlarına en verimli şekilde bilgi sağlayacak maliyetleme yönetiminin uygulanması, bugünün rekabet koşulları göz önünde bulundurulduğunda çok önemli bir adım olmaktadır. Bugün hala yöneticilerin karar alma sürecine destek olacak en uygun ve en doğru maliyet bilgilerini sağlayacak yeni ve farklı yöntemler araştırılmaktadır. KTM ise GPK ve FTM'nin birleştirilmesinde oluşturulmuş bir yöntem olarak birçok işletmeye faydalı maliyet bilgileri sağlayarak uygulanabilirliğini korumaktadır. 


\section{KAYNAKÇA}

AHMED, S. A. ve MOOSA, M. (2011). "Application of Resource Consumption Accounting (RCA) in an Educational Institute", Pakistan Business Review, January, 755-775.

AKTAŞ, R. (2013). "Yeni Bir Maliyet ve Yönetim Muhasebesi Yöntemi Olarak Kaynak Tüketim Muhasebesi", Muhasebe ve Finansman Dergisi, (Nisan), 55-76.

ALTINBAY, A. (2006). "Etkin Bir Maliyet Yönetim Sistemi Olarak Hedef Maliyetleme Sistemi ve TMMT Uygulaması", Dumlupınar Üniversitesi Sosyal Bilimler Dergisi, (16), 141-164.

CHARLOS, P. ve BADER, A. H. (1986). "High-Tech Production: The Impact on Cost Reporting Systems", Journal Of Accountancy, 106-107.

ELMACI, O. (2013). "İşletme Performans Yönetiminde Kaynak Tüketim Muhasebesi (KTM) Yöntemi ile Bütünleştirilmiş Balance Scorecard (BSC) Uygulamasına İlişkin Bir Model Önerisi", International Conference On New Directions İn Business, Management, Finance And Economics, 12-14 Eylül, Famagusta Northern Cyprus.

FISHER, J. G. ve KRUMWIEDE, K. (2012). "Product Costing Systems: Finding The Right Approach", The Journal Of Corporate Accounting \& Finance, March/April, 43-51.

FRENCH, R. L. (1980). "How Much Does is Cost? Does Anybody Know?", Industrial Management, 18-19.

GÜMÜŞ, Y. (2012). Lojistik Faaliyetler ve Maliyetler. Gazi Kitabevi, Ankara.

GÜRSOY, A., YÖNTEM, O. ve ONURSAL, S. (2016). "Faaliyet Tabanlı Maliyet Sistemi ile Doğru Maliyetlendirme Araçları: Otomotiv Sektöründe Bir Uygulama", Doğuş Üniversitesi Dergisi, 17 (1), 67-81.

HACIRÜSTEMOĞLU, R. ve ŞAKRAK, M. (2002). Maliyet Muhasebesinde Güncel Yaklaşımlar. Türkmen Kitabevi, İstanbul.

KARACA, N. ve KÜÇÜK H. (2017). "Kaynak Tüketim Muhasebesi Temelinde Ürün Maliyetlerinin Hesaplanması-Karşılaştırmalı Bir Uygulama", İşletme Araştırmaları Dergisi, s.353-37.

KARĞIN, S. (2013). "Faaliyet Tabanlı Maliyetleme Yönteminin Yükselişi ve Düşüşü", Muhasebe ve Finansman Dergisi, s.21-40.

KAYGUSUZOĞLU, M. (2010). "Üretim Maliyetlerindeki Yapısal Değişmelerin Nedenleri ve Maliyetleme Kararlarına Etkileri", Elektronik Sosyal Bilimler Dergisi, 9 (34), 240258.

KÖSE, T. ve AĞDENIZ, Ş. (2015). "Kaynak Tüketim Muhasebesinde Kapasite Maliyet Yönetimi", Muhasebe ve Denetime Bakış, (Haziran), 51-74.

KURTLU, A.E., (2016). "Kaynak Tüketim Muhasebesi: Silah Fabrikası Örneği", Niğde Üniversitesi İktisadi ve İdari Bilimler Fakültesi Dergisi, 9 (3), 1-14. 
KURTLU, A., UÇAR, M., ÇOBANOĞLU, S. (2017). "Çağdaş Maliyet Yöntemlerinin Konaklama İşletmelerinde Uygulanabilirliği Üzerine Bir Araştırma", İşletme Araştırmaları Dergisi, 9 (3), 521-546.

LEWIS, R. J. (1993). Activity-Based Costing For Marketing And Manufacturing. Quorum Books, Londra.

MERWE, A. V. D. ve KEYS, D. E. (2002). "The Case For Resource Consumption Accounting", Strategic Finance, 31-36.

OKUTMUŞ, E. (2015). "Resource Consumption Accounting with Cost Dimension and an Application in a Glassfactory", International Journal Of Academic Research in Accounting, Finance And Management Sciences, 5 (1), 46-57.

ÖĞÜNÇ, H. ve TEKŞEN, Ö. (2018). "Kaynak Tüketim Muhasebesi Yaklaşımının Tuğla Üretim İşletmesinde Uygulaması ve Karşılaştırmalı Analizi", Muhasebe Bilim Dünyası Dergisi, 20 (2), 389-417.

ÖKER F. (2003). Faaliyet Tabanlı Maliyetleme Üretim ve Hizmet İşletmelerinde Uygulamalar. Literatür Yayınları, İstanbul.

PEACOCK, E. and Juras, P. (2006). "Alternative Costing Methods: Precision Paint", Strategic Finance, 88 (2), 50-55.

PERKINS, D. and Stovall, O. S. (2011). "Resource Consumption Accounting - Where Does It Fit?", Journal Of Applied Business Research, 27 (5), 41-51.

TSE, M. S. C. ve GONG, M. Z. (2009). "Recognition of Idle Resources in Time-Driven Activity-Based Costing and Resource Consumption Accounting Models", Journal of Applied Management Accounting Research, 7 (2), 41-54.

UNUTKAN, Ö. (2010). "Faaliyet Tabanlı Maliyet Sistemi ve Bir Uygulama", Mali Çözüm Dergisi, 97.

WANG, Y., ZHUANG, Y., HAO, Z., Lİ, J. (2009). "Study on The Application Of RCA in College Education Cost Accounting", International Journal of Business and Management, 4 (5), 84-88.

WEBER, S. A. ve CLINTON, D. (2004). "Resource Consumption Accounting Applied: The Clopay Case", Management Accounting Quarterly, 6 (1), 1-14.

WEGMANN, G. (2009). "The Activity-Based Costing Method: Development and Applications", The IUP Journal Of Accounting Research, 8 (1), 7-22.

WHITE, L. (2009). "Resource Consumption Accounting: Manager-Focused Management Accounting", The Journal Of Corporate Accounting \& Finance, (May/June), 63-77. 